Article received on 02 September 2013

Article accepted on 30 November 2013

UDC

\title{
MUSIC DRAMA AND POLITICS: \\ PHILIPPE LACOUE-LABARTHE AND ALAIN BADIOU ON RICHARD WAGNER'S IDEA OF THE GESAMTKUNSTWERK
}

\author{
Erik Vogt \\ Trinity College in Hartford (USA) \\ Department of Philosophy
}

\begin{abstract}
This paper sketches the debate between Philippe Lacoue-Labarthe and Alain Badiou concerning Richard Wagner's idea of the Gesamtkunstwerk. Following in part the account of the Gesamtkunstwerk that was developed in Theodor W. Adorno's pivotal text In Search of Wagner, Lacoue-Labarthe regards the notion of Gesamtkunstwerk as the central key for unlocking the implications of Wagner's theory and practice of music drama. That is to say, Lacoue-Labarthe claims that the fusion of art and politics characterizing the Gesamtkunstwerk can only be grasped by unearthing the conception of (romantic) aesthetics that underlies Wagner's staging of the relationship between art and politics. Lacoue-Labarthe identifies Wagnerian aesthetics as the anticipation of national-aestheticism (a term that Lacoue-Labarthe elaborates in the context of his reading of Heidegger's deconstruction of aesthetics) that finds its completion in National Socialism. Consequently, Wagner's art taking figure in the Gesamtkunstwerk engenders totalitarian politics. In critical opposition to Lacoue-Labarthe, Alain Badiou both relegates the idea of the Gesamtkunstwerk to the realm of mere ideology and demonstrates that the former obscures the complex relationship between art and politics that is actually engendered in Wagner's music dramas. Once the idea of the Gesamtkunstwerk is dismissed as the central category of Wagnerian artistic production, one can return to Wagner's music dramas as sites both for a "music of the future" and a different conception of politics.
\end{abstract}

Key words: Richard Wagner; Philippe Lacoue-Labarthe; Alain Badiou; Music drama; Gesamtkunstwerk

The nature of the relationship between Richard Wagner's conception (and praxis) of music drama and his idea of the Gesamtkunstwerk has remained a controversial issue in the literature on Wagner. Referring to the fact that Wag-

\footnotetext{
* Author contact information: erik.vogt@trincoll.edu
} 
Vogt, E.: Music Drama and Politics: Lacoue-Labarthe and Badiou ... (62-70)

ner's writings employ the idea of the Gesamtkunstwerk rather sparingly, ${ }^{1}$ several commentators have argued that a strict conceptual distinction between music drama and Gesamtkunstwerk has to be maintained; for while the Wagnerian music drama defines and enacts innovative relations between language, music, and theatre - relations that are supplemented by a notion of myth conceived of as artistic and the religious generation of meaning providing a normative orientation for the audience - the Gesamtkunstwerk designates the site at which the music drama passes into the public realm in the guise of a festival (Bayreuth); ${ }^{2}$ moreover, the Gesamtkunstwerk ultimately signifies a cultural vision, a visionary ideal that "is merely an ideological construct which he soon abandoned and which has no material significance in terms of his dramaturgical praxis;"'3 consequently, "the ideology of the 'total work of art' (...) needs to be distinguished from its aesthetic and dramaturgical praxis." 4

Other commentators claim, however, that a strict separation between music drama and Gesamtkunstwerk should not be drawn, unless one wants to dissolve the very unity of both aesthetic and philosophic-historical considerations characterizing the novel aspect of Wagner's writings on music drama. In other words, the idea of the Gesamtkunstwerk provides precisely the interpretive key for an adequate understanding of Wagnerian music drama. Theodor W. Adorno's seminal study In Search of Wagner is a case in point. ${ }^{5}$ By way of immanent critique, Adorno examines, in the name of the authentic Gesamtkunstwerk as oppositional dissonance against the systematic order of bourgeois-capitalist society, the "categorical aesthetic-musical and philosophical-historical norms" that co-determine Wagner's idea of the Gesamtkunstwerk. ${ }^{6}$ That is to say, Adorno distinguishes between different models of the Gesamtkunstwerk to be found in Wagner's writings. On the one hand, the Gesamtkunstwerk as protest against the bourgeoisification of art (in opera) clearly presupposes the prior revolutionising of societal relations, thereby affirming the thesis that only a truly free society

\footnotetext{
${ }^{1}$ Cf. Udo Bernbach, Der Wahn des Gesamtkunstwerks, Stuttgart/Weimar, Verlag Metzler, 2004, 173.

2 Ibid. 175.

${ }^{3}$ Dieter Borchmeyer, Richard Wagner: Theory and Theatre, Oxford, Clarendon Press, 1991, 68.

${ }^{4}$ Ibid. 68.

5 Theodor W. Adorno, In Search of Wagner, London/New York, Verso, 2009.

${ }^{6}$ Cf. Richard Klein, "Zwangsverwandtschaft. Ueber Naehe und Abstand Adornos zu Richard Wagner", Richard Wagner und seine Zeit, ed. E. Kiem and L. Holtmeier, Laaber, Laaber Verlag, 2003, 183 - 236; 188. In what follows, Klein's seminal arguments regarding the affinity between Adorno and Wagner are paraphrased - an affinity that is owed to the fact that both remain faithful to a type of Left-Hegelianism transposed into the realm of aesthetics.
} 
provides the proper conditions for the existence of the Gesamtkunstwerk; in this respect, Adorno agrees with Wagner's insistence on the critical elucidation of the very social and historical conditions necessary for a successful realisation of the Gesamtkunstwerk. On the other hand, by simultaneously conceiving of the Gesamtkunstwerk as aesthetically representative of societal emancipation, Wagner renders the Gesamtkunstwerk ambiguous in that it becomes impossible to decide as to whether it contributes to societal emancipation in a real manner, represents it merely in the realm of Schein, or replaces the latter ideologically. Thus, while Adorno endorses the Gesamtkunstwerk's artistic figuration of the antagonism between the autonomy of artistic individuality and collective heteronomy and recognises the Gesamtkunstwerk as accomplishing the dissolution of general genre norms in favour of the consistent individualisation of aesthetic construction, thereby questioning, from a nominalist perspective, the "form-conventions of the traditional opera and the allegedly natural and eternal structural principles of music", 7 he critically departs from Wagner's move to sacrifice artistic individuality to the societal status quo, thereby falsely transforming the not yet realized socio-political utopia into an aesthetic state of the present ${ }^{8}$ moreover, he rejects Wagner's claim that intoxication is a necessary condition for the Gesamtkunstwerk because it accomplishes a levelling of the constitutive difference between aesthetic and social reality, thereby generating the illusion of the ideal unity of the Gesamtkunstwerk - an illusion that must be deciphered as phantasmagoria. ${ }^{9}$ Wagner's voluntaristic attempt at a realisation of the aesthetic totality of the Gesamtkunstwerk in the absence of the proper socio-political conditions, as well as his mobilisation of intoxication to enforce reconciliation between the individual and the collective account for the merely arbitrary and non-dialectical synchronisation of poetry, music, and theatre; ${ }^{10}$ furthermore, this loss of artistic mediation results in a multi-media phantas-

\footnotetext{
7 Gyorgy Markus, “Adorno’s Wagner”, Thesis Eleven, 1999, 56, 25 - 55; 29.

8 Cf. Theodor W. Adorno, op. cit. 91.

9 Ibid. 93.

10 Adorno writes: "Like Nietzsche and subsequently Art Nouveau (...) he would like single-handed to will an aesthetic totality into being, casting a magic spell and with defiant unconcern about the absence of the social conditions necessary for its survival" - Theodor W. Adorno, ibid. 90. And: "For this reason the Wagnerian totality, the Gesamtkunstwerk, is doomed to failure. To disguise this is not the least of Wagner's tasks in running together all the different elements into each other. (...) The whole no longer achieves unity, because its expressive elements are made to harmonise with each other according to a pre-arranged design. (...) The formal premisses of an internal logic are replaced by a seamless external principle in which disparate procedures are simply aggregated in such a way as to make them appear collectively binding" - ibid. 91.
} 
Vogt, E.: Music Drama and Politics: Lacoue-Labarthe and Badiou ... (62-70)

magoria that not only barely conceals its contingent, that is, disintegrative and inconsistent character, but also, by veiling all traces of the labour that entered the production of the music drama, stages technologically generated ecstatic sensations announcing simultaneously the birth of fascism and of the culture industry in the Gesamtkunstwerk. ${ }^{11}$ This inversion of reality into phantasmagoria enacted by the Gesamtkunstwerk is accompanied by expelling any concern with emancipative "politics from opera", ${ }^{12}$ that is, by a de-politicisation for the sake of affirming myth (and a mythologizing of music itself) that "prefigures that nightmarish regression into an archaic past which completes its trajectory in fascism."13 Thus, Adorno insinuates an indissoluble link between the synthesising and totalising programme of the Gesamtkunstwerk and political totalitarianism in that the Gesamtkunstwerk, by producing intoxicating global sound effects, by employing overpowering beat and authoritarian-regressive theatrical elements, and by enforcing in a repetitive manner the same motives as the main construction principle, violently incorporates the human collective through calculated effects, thereby fusing the latter with the mythical construction of the German Volk.

These two opposed accounts of the relationship between the practice of music drama and the idea of the Gesamtkunstwerk can also be discerned in the recent Auseinandersetzung between Philippe Lacoue-Labarthe and Alain Badiou regarding the actuality of Wagner's work. That is to say, the exclusive focus of Lacoue-Labarthe's reading of Wagner lies on the Gesamtkunstwerk; what is more, he reiterates not only Adorno's contention that the Wagnerian Gesamtkunstwerk marks the moment in which 'the first mass art had just been born, through music (through technology), ${ }^{14}$ but also Adorno's claim that the Gesamtkunstwerk has to be grasped as the proto-fascist aestheticisation of politics, that is, as a configuration of (anti-Semitic) politics involving the constitution of the German Volk. Lacoue-Labarthe stipulates that both Wagnerian art and National Socialism must be interpreted in terms of national-aestheticist strategies aiming for the re-birth of ancient tragedy. ${ }^{15}$ Citing certain remarks by Goebbels

${ }^{11}$ Cf. Andreas Huyssen, Adorno in Reverse. From Hollywood to Richard Wagner", New German Critique, 1983, 29, 8 - 38.

12 Theodor W. Adorno, op. cit. 103.

13 Ibid. 36.

14 Philippe Lacoue-Labarthe, Musica Ficta, Stanford, Stanford University Press, 1994, xx.

15 Lacoue-Labarthe extracts the term "national-aestheticism" from his reading of Martin Heidegger's deconstruction of aesthetics which engages a complex mimetic relationship between the ancient and the modern. This clear indebtedness to the Heideggerian framework may also explain why Lacoue-Labarthe's treatment of Wagner completely lacks Adorno's insistence of the very progressive elements in Wagner that allow for Wagner's possible re- 
and by Syberberg, he demonstrates that National Socialist politics were centrally predicated on the notion of the Gesamtkunstwerk: ${ }^{16}$ more succinctly, the Gesamtkunstwerk served as the political model of National Socialism, "since it was the intention of the Festspiel of Bayreuth to be for Germany what the Greater Dionysia was for Athens and for Greece as a whole: the place where a people, gathered together in their State, provide themselves with a representation of what they are and what grounds them as such." ${ }^{17}$ Lacoue-Labarthe continues: "Which does not merely mean that the work of art (...) offers the truth of the polis or the State, but that the political itself is instituted and constituted (...) in and as a work of art." 18 Moreover, Wagner's political fiction of the German myth is very close to the Nazi myth in that in both myth functions as "the power that is in the gathering together of the fundamental forces and orientations of an individual or a people, that is to say the power of a deep, concrete, embodied identity;" in short, both Wagner and National Socialism are characterised by an "onto-typological interpretation of myth" according to which myth "is the figuration of a type conceived both as a model of identity and as that identity formed and realized." 19

In sum, Wagner's national-aestheticist Gesamtkunstwerk constitutes, for Lacoue-Labarthe, the culmination and completion of Romanticism in that it keeps from romantic aesthetics the religious-political function of art to ground in myth the self-presentation of a people; that is, Wagner's artistic project is essentially an aesthetic project characterized by the preponderance of the aesthetic over art. This primacy of the aesthetic in Wagner's Gesamtkunstwerk is the result of the subordination of language under music generating an infinite

demption, that is, for Adorno's attempt to wrest Wagner from the clutches of National Socialism. Since Lacoue-Labarthe completely abstains from any analysis of the musical elements, he necessarily has to ignore not only Wagner's novel articulation of the relation between consonance and dissonance at the threshold of atonality and his emancipation of colour, but also the possibility of identifying in Wagner's nihilistic decadence those very moments from which "the forces of the future" might be extracted - Theodor W. Adorno, op. Cit. 142. Ultimately, Lacoue-Labarthe seems to share Heidegger's verdict that Wagnerian music drama, by privileging music over poetry, constitutes simply an aesthetic rendition of some metaphysics of feeling.

${ }^{16}$ Cf. Lacoue-Labarthe, Heidegger, Art and Politics, Oxford, Blackwell, 1990, 61 - 63.

17 Ibid. 64.

${ }^{18}$ Ibid. 64.

19 Ibid. 94. According to Lacoue-Labarthe, this 'mythopoiesis', this 'pure self-formation' finding 'its truth or its verification as the self-foundation of the people', can also account for both Wagnerian and National Socialist anti-Semitism because both claim that the 'Jews' are without myths and therefore incapable of entering into this process of self-fictioning characteristic of onto-typological accounts of myth. Ibid. 96. 
Vogt, E.: Music Drama and Politics: Lacoue-Labarthe and Badiou ... (62-70)

melocentrism that allows for a quasi-totalitarian communal fusion animated by "the ultimately romantic desire (...) for a religious, that is to say political, art, in the sense that Attic tragedy, according to his idealist myth, is such a (...) festival and celebration of the people or of the City." 20

Thus, Alain Badiou is right to claim that Wagner's artistic apparatus represents for Lacoue-Labarthe a composite that consists of evocations of originary myths, technological amplifications of operatic, orchestral, and musical techniques, totalizing gestures bringing about the closure of a certain type of opera in Western music, and, reinforcing the first three features, a type of unification that, in the guise of endless melody, not only dissolves language and synthesizes all internal differences, but also renders music mythological in that the Wagnerian leitmotif is the very method by means of which the mythical elements of plot and narrative are musically over-determined. ${ }^{21}$ However, Lacoue-Labarthe's construction of a "mythological, technological, totalizing figure of Wagner, in which the music effects a synthesis of the mythological imperatives," 22 must be rejected because it "prescribes a certain Wagner" on the basis of both "a theory of politics and aestheticisation." ${ }^{23}$ Thus, in order to find access to a "new Wagner", that is, to Wagnerian art as a creative project that still holds promises for the future, Badiou maintains that one has to dismiss the Gesamtkunstwerk as mere slogan ${ }^{24}$ and must instead "venture into Wagnerian fragmentation and 'localization: at the point where continuity and dissonance, the local and the global, confront each other both musically and dramatically." 25 That is to say, only if the Wagnerian music dramas are uncoupled from the totality of the Gesamtkunstwerk, will it be possible to re-think Wagnerian art in such a way that is no longer fused with totality, but rather negates the latter.

Recounting Lacoue-Labarthe's main accusations against Wagnerian art - the imposition of seamless continuity in the form of his theory of endless melody that is based on the model of subjective affect for the sake of erecting identities, the dialectical subsumption of differences, dissonances, discontinuities under the figure of final reconciliation; the subjection of music to leitmotif - Badiou

\footnotetext{
${ }^{20}$ Ibid. 100.

${ }^{21}$ Alain Badiou, Five Lessons On Wagner, London/New York, Verso, 2010, 19.

22 Ibid, 21.

${ }^{23}$ Ibid. 10. Moreover, Lacoue-Labarthe's construction of Wagner is also owed to the imperative of nüchtern (sober) art borrowed from Friedrich Hoelderlin - an imperative directed against any attempted restoration of "great art".

24 Ibid. 15.

${ }^{25}$ Ibid. 83 - 84. The central reference point for Badiou's "deconstruction" of Wagner is without doubt the Boulez-Chéreau-Regnault production of the Ring des Nibelungen from the 1970s - ibid. 6.
} 
puts forth his hypothesis regarding the Wagnerian interplay between music and drama in which music, far from subordinating rhythmic and melodic aspects under some pre-conceived coercive totality, marks the very medium in which dramatic possibilities are created that engender unpredictable transformations and transitions testifying to the fundamental plasticity of metamorphosis rupturing the teleological narrative structure of Wagner's music dramas and its characters. ${ }^{26}$ The focus on music and on its processes of formal transformation reveals that music qua music is the site of metamorphosis and transition immanently questioning Wagnerian narrative, particularly in its mythical and monumental figurations. In this context, Badiou attempts to demonstrate that the leitmotif, far from simply being a technique guaranteeing mythical identity and continuity, "also functions as a non-descriptive, internal musical development, with no dramatic or narrative connotations whatsoever." ${ }^{27}$ Consequently, Wagner's leitmotifs constitute "a unique nexus between discontinuity or transformation (with its potential for disintegration and destruction), on the one hand, and continuity and persistence (with its potential for narrative dogmatism), on the other." ${ }^{28}$ Furthermore, Wagnerian music does not produce types in Lacoue-Labarthe's sense, but rather generates non-dialectical subjective splits exposing (the figures of) Wagner's music dramas to an inner heterogeneity that cannot be sublimated into, or reconciled with, some affirmative finale. ${ }^{29}$ Wagner's music dramas cannot be totalized into the Gesamtkunstwerk because they represent an embodied multiplicity of artistic configurations and each artistic configuration constitutes a singular exploration 'of a possibility of ending;' ${ }^{30}$ that is to say, each music drama elaborates musically the consequences of its own innovative mode of thought regarding the possibility of ending. For instance, Badiou claims that, whereas the ending of Goetterdaemmerung must be interpreted as the utter destruction of mythology, ${ }^{31}$ both Die Meistersinger von Nuernberg and Parsifal concern the question of the "relationship between the old and the new, between tradition and

\footnotetext{
${ }^{26}$ Ibid. 88.

27 Ibid. 20.

${ }_{28}$ Martin Scherzinger, "Wagner Redux: Badiou on Music for the Future", Contemporary Music Review, 2012, 31, 474.

29 Alain Badiou, op. cit., 90 - 98. Here, Badiou refers to Tannhaeuser and its threefold split: the split regarding love; the historical split 'between the strictly ordered world of chivalry and the anarchic world of individual wandering;' finally, the 'symbolic split' between the 'pagan gods (...) and the God of the Christian religion.' Ibid. 92 - 93.

30 Ibid. 99.

${ }^{31}$ Ibid. 105. This claim contrasts Lacoue-Labarthe's thesis that Goetterdaemmerung presents the mythical self-enclosure of the Ring des Nibelungen.
} 
Vogt, E.: Music Drama and Politics: Lacoue-Labarthe and Badiou ... (62-70)

innovation." ${ }^{32}$ One of the lessons of Wagnerian music consists therefore in the recognition that art cannot be solely "grounded in formal subtraction," that is, in a simple break with the past that would neglect its transformative potential, but must rather be grounded in an incorporation or repetition of the past such that its disruptive effects can continue and persist in the present. ${ }^{33}$

What is more, this latter predicament of music is shared by politics; for Badiou shows that the subject of Parsifal is precisely the possibility of a new, non-religious, non-transcendent "modern ceremony" understood as a generic "community's mode of self-representation." 34 Although Parsifal fails in bringing about a Darstellung of modern ceremony because Wagner's conception of Bayreuth as theatre for ceremony redoubles representation and is therefore in danger of reinstating closure, ${ }^{35}$ Wagner's idea of modern ceremony addressed to a generic (not to a mythical Volk) cannot be simply dismissed; for Badiou reminds us that "the question as to whether the Crowd declares itself (...) cannot be exclusively recapitulated in collective figures of revolt. (...) It must also put forward, examine and produce its own consistency." ${ }^{\prime 36}$ Even though Parsifal ultimately does not change "the ceremony into something new", its philosophicalpolitical lesson nevertheless consists in inviting us "at least to be able to get ready to intrude into future celebrations, that is, to anticipate or have the necessary prerequisites for the future celebration." 37

Badiou claims that it is possible to extract both a notion of art and a notion of politics from Wagner's work that are no longer complicit with myth, the violent fashioning of a people, and the totalisation of the arts in the name of the Gesamtkunstwerk, as long as one pays heed to "five rules (...) concerning what greatness, as distinct from totality or from messianic will, might be." ${ }^{38}$ These five rules or directions comprise the creation of new (subjective) possibilities; the multiplicity of hypotheses operative in and tolerated by Wagner's music dramas; the toleration of the split subject, of heterogeneity; non-dialectical figures of resolution; transformations that no longer operate under the guidance of teleological principles of development and of affirmative dialectic. ${ }^{39}$

\footnotetext{
32 Ibid. 107.

33 Ibid. 108. While Meistersinger accomplishes this productive-disruptive repetition of the past within the realm of German art (and not of politics), Parsifal subjects Christianity to this very same operation, thereby in a way both saving and abolishing it - ibid. $102-103$.

34 Ibid. 147.

35 Ibid. 151.

36 Ibid. 158.

37 Ibid. 159.

38 Ibid. 130.

39 Ibid. $130-131$.
} 
Ultimately, Lacoue-Labarthe and Badiou starkly differ regarding the conception of politics they claim can be extracted from Wagnerian music drama. Fully subsuming the music dramas under the idea of the Gesamtkunstwerk, Lacoue-Labarthe draws the conclusion that Wagnerian art marks the closure of the political because it is suffused with the will to realise a communal and national essence based on the identity principle of the German Volk; moreover, this imperative force of the figure of the German Volk accounts for Wagner's metaphysical politics and its totalitarian impulse. However, by insisting on the nominalist necessity to keep the music dramas separate from the totalising framework of the Gesamtkunstwerk, Badiou suggests that Wagner's singular music dramas ought to be grasped as artistic configurations that precisely disrupt the monophonic totality invoked by the Gesamtkunstwerk since they contain traces of a different politics challenging precisely Lacoue-Labarthe's assumption that Wagnerian art simply presents politics in terms of a quasi-religious binding identitarian force. Consequently, Wagner's music dramas operate as different and differing singular artistic sites producing not some essence of the political but rather embodied multiplicities that afford at the very least glimpses at the power of generic humanity irreducible to any identitarian assignation. ${ }^{40}$

${ }^{40}$ Here, Badiou comes close to Adorno's contention that Wagner's attack on bourgeois art occurred "in the name of "real', that is to say, a whole and free humanity" - Theodor W. Adorno, op. cit. 99. 